DOI

http://dx.doi.org/10.1590/2236-463320151111

Ângelo Agostini e a Charge

no Crepúsculo Imperial -

Apontamentos Preliminares acerca

da Questão Abolicionista

\title{
Ângelo Agostini and the Cartoons at the Imperial Twilight - Preliminary Notes on the Abolition in Brazil
}

\section{Vinícius Liebel}

Pontifícia Universidade Católica do Rio Grande do Sul (PUCRS)

\section{Resumo}

0 presente artigo tem por objetivo apontar questões pertinentes à análise da obra do chargista oitocentista Ângelo Agostini, bem como apresentar questões relevantes à análise de imagens no campo historiográfico. Para tanto, o texto localiza a produção do artista em termos contextuais, localizando-o como um herdeiro de uma arte que tem no século XIX sua primeira era de ouro: a charge. Em seguida, após breves considerações acerca da análise de imagens nos estudos históricos, parte-se para a interpretação de charges produzidas por Agostini que encontram no grande tema do abolicionismo seu pano de fundo.

\section{Abstract}

This paper aims at pointing out relevant questions on the analysis of the work of nineteenth-century cartoonist Ângelo Agostini, as well as to present pertinent arguments on the analysis of images in the historiographical field. To this end, the text locates the artist's production in contextual terms, as an heir to an art tradition that has in the nineteenth century its first golden age: the political and social cartoon. Then, after a brief consideration of the analysis of images in historical studies, two cartoons produced by Agostini on the great theme of abolitionism are interpreted as exemplary analysis.

Palavras-chave

Ângelo Agostini, Charges, Abolicionismo, Análise de Imagens.

Keywords

Ângelo Agostini, Political Cartoons, Abolitionism, Analysis of Images. 
1 ARGAN, Giulio Carlo. Arte Moderna. São Paulo: Cia. das Letras, 1998. p. 64.

2 GAY, Peter. A Experiência Burguesa da Rainha Vitória a Freud - O Cultivo do Ódio. São Paulo: Cia. das Letras, 1995. p. 403.

3 MELOT, Michel. Daumier, I'Art et la République. Paris: Les Belles Lettres, 2008.
It is in the Paris of mid-nineteenth century that comes to light the aesthetic and stylistic matrix which will determine the production of what would be called charge (cartoon) in Brazil. In particular, the feather that drafted the style present in many Brazilian magazines and newspapers until the early decades of the twentieth century was that of Honoré Daumier, a French artist who popularized the art of satirical drawing with his portraits of Louis-Philippe and chronicles of French politics, from the July Monarchy until the fall of the Second Empire.

Politics and society were the main objects of his works, and his criticisms, always disguised by the veil of humor and cynicism, would target some of the main political actors of the period. Indeed, Daumier seems to have been the first artist engaged, at least nominally, in a political debate,

... the first to build the foundations of art on a political interest (seeing in politics the modern form of morality), the first to use mass communication, the press, to influence social behavior through art. The press was not only a means of disseminating images for him; It was the technique that produced images capable of reaching and influencing his audience.'

It must also be considered that the rise of Daumier in the Parisian art scene and politics took place under the repression of a newly restored government and still unsure of its position. Particularly in 1835, censoring laws were introduced and the critics of government were charged according to them. Cartoonists and illustrators of the press were particularly targeted, especially Daumier, and he and his publisher were taken to court dozens of times. This did not prevent him from keeping criticizing and satirizing the government. He may, perhaps, have curbed some of his impulses. In the words of Peter Gay, "the power of repression prevents a nation to achieve the aggressive political humor it deserves. In fact, they get the humoristic aggression that their government can tolerate". ${ }^{2}$ That was certainly the case, but Daumier's feather continued to test the limits and patience of censors with his elaborated features and his cynical approach to the French political landscape. His role as observer and critic of French politics exposed him among the artists engaged to the Republican cause of the period, making him an active member of the French public debate ${ }^{3}$, even under censorship.

Characterized by a strong sense of accuracy, Daumier's production also had a remarkable influence on literary and artistic movements, especially naturalism and realism. The rawness of his canvases and the expressive details in his lithographs and cartoons make his work representative of the context in which the writings of Baudelaire and Flaubert, as well as Victor Hugo's realistic romanticism, formed the Parisian aesthetic-literary backdrop of the second half of the nineteenth century.

Daumier reaches the height of his popularity in the mid-nineteenth century, especially between the 1830s and 60s, when most of the more than four thousand images of his authorship were produced. His drawings were almost omnipresent in Paris, either as lithographs for sale on the streets or on the pages of the illustrated newspaper Le Charivari, which (with its circulation ranging 2000-3000 daily copies) was read by different groups of the urban middle class. It was through the Charivari that the general public came into contact with the work of Daumier, and it was also through this newspaper that his influence on new artists and illustrators was spread. 
SALGUEIRO, Heliana Angotti. A Comédia Urbana - de Daumier a Porto Alegre. São Paulo: Fund. Armando Álvares Penteado, 2003. p. 12.
5

Ibid. p. 96-7.

BERGSON, Henri. 0 Riso. São Paulo: Martins Fontes, 2001

7

SALGUEIRO, Heliana Angott. Op. Cit.

8

The adjective "auctorial" is used here to reinforce and, in a way, justify the identification of Porto Alegre as the initiator of this technique in Brazil. This insertion is necessary for belonging to the Graphica Pernambucana, the first known experience with the genre in Brazil. It was in the front page of the newspaper 0 Carcundão that a drawing of a donkey (a representation of the Restoration Party) attempting to uphold a Greek column (representing the Throne Columns Society, which defended Pedro l's absolutism) was published in 1831 (CAMPELLO, Silvio; CAVALCANTE, Sebastião. Ilustração e Artes Gráficas - Periódicos da Biblioteca pública do Estado de Pernambuco. São Paulo: Blucher, 2014). However, the authorship of this cartoon is unknown.
The Origins of Brazilian Satire in Nineteenth-Century Paris

The biographies of two artists end up being decisive in the development of the satirical art of "charge" in nineteenth-century Brazil. In 1831, Manuel de Araújo Porto Alegre, an artist from Rio Grande do Sul and Debret's disciple, arrives in Paris to continue his studies in painting. There, Porto Alegre comes into contact with the work of Daumier, absorbing not only his technique and style, but also the effervescent spirit of a cosmopolitan city in constant transformation, moved by symbols, images, representations and models of a "time without boundaries." ${ }^{4}$ The momentum of urban, political and social transformations lived by Daumier and Porto Alegre in Paris had a profound influence on the life, technique and worldview of both of them.

When he returns to Brazil, in 1837, Porto Alegre brings with him the vision of the satirical press and the political and social representations of modernity. The voracious criticism of customs and traditions that no longer conform to modern times finds in humor his most faithful companion. Humor acts precisely in the denunciation of the idiosyncrasies of a time that advances more than its own people. The contradictions between cities that grow and advance technologically, on one side, and sociability confined to the eighteenth century on the other, would be some of the themes most often explored by satirical chroniclers.

The city of nineteenth century presents itself therefore as a multi-stage where relationships are made and fall apart, where actors present unpredictable and even contradictory behaviors, sometimes dashing in all directions to survive. This dispersion was the keynote in the nineteenth century Rio de Janeiro and marks Araújo Porto Alegre's career. ${ }^{5}$

In fact, the mordant humor acts over the customs, as Bergson ${ }^{6}$ points out, through the humiliation of the non-conformed and of everything that did not fit in this new vision of the modern. Rio de Janeiro, which intended to be cosmopolitan and avant-garde, reflected the Parisian time, taking the City of Lights as a model. Porto Alegre would be responsible for translating it in the form of laughter with the stylistic influence of Daumier, as Salgueiro ${ }^{7}$ indicates.

Porto Alegre's first contribution appears in 1837, and it is considered the first Brazilian auctorial ${ }^{8}$ "charge". Entitled A Campainha e o Cujo (The Bell and the One), this cartoon portrays the director of the government newspaper Correio Oficial getting a bag of money while making noise with his bell. The Brazilian "charge" emerges in denunciation of corruption and malfeasance, condemned to repeat the same message in the following centuries. The scenario is the federal capital, with its modern conveniences, such as public lighting (oil lighting, as gas street lighting was to be set up in São Paulo, the first city in the country to receive the service, in 1854), and its new social conventions. 


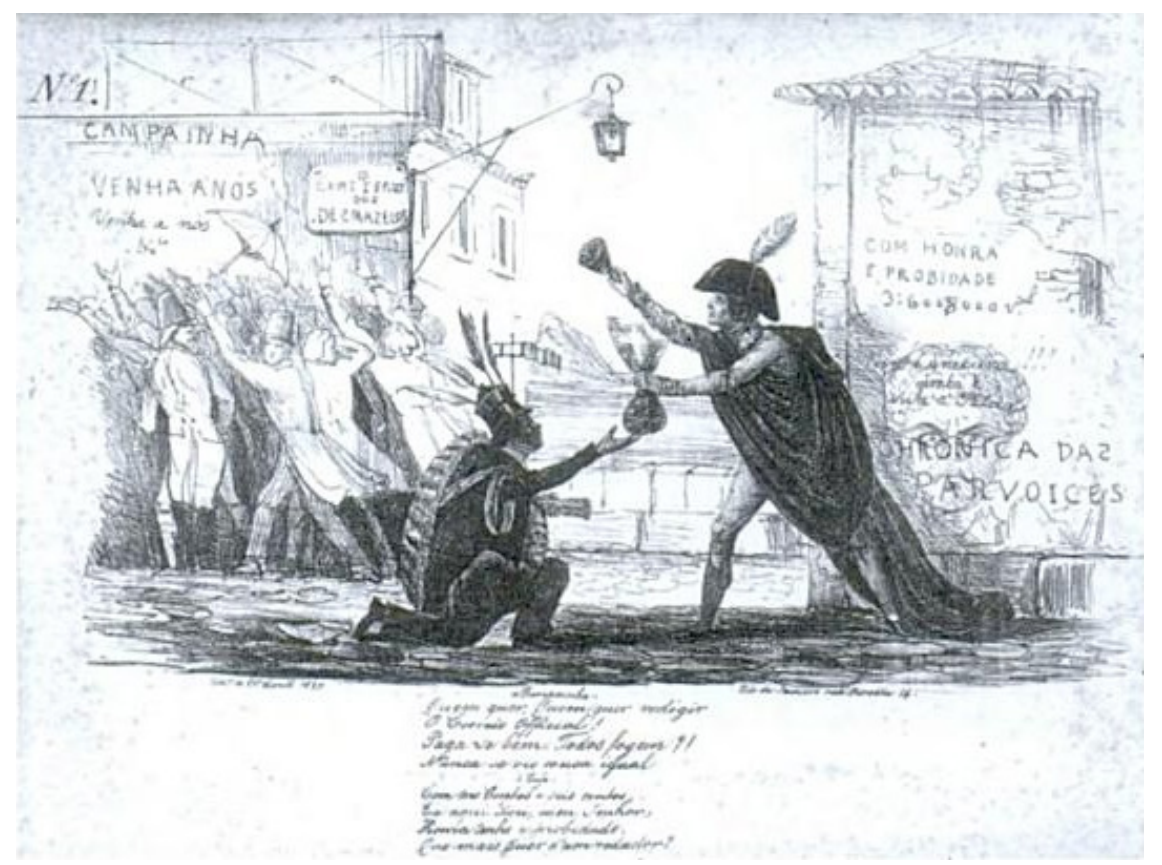

Image 1 - PORTO ALEGRE, Manuel de Araújo. A Campainha e o Cujo. Litography. 1837. Fund. Biblioteca Nacional

Porto Alegre kept his satirical craft parallel to his painting career. In 1844 he founded the satirical magazine Lanterna Mágica (Magic Lantern), which had in the social humor its main theme. His entrepreneurship is so fully manifested, even though he did not became the most prolific cartoonist of the imperial period. This post was reserved for an artist that was literally born when The Magic Lantern was being planned.

The year 1843 marks the birth of Ângelo Agostini, Italian who would soon have his life linked to humor and Brazil. Before arriving in Brazil, Agostini spent his childhood in a Paris still dominated by Daumier and the Charivari. The French cartoonist left the satirical publication only in 1860, a year after Agostini's departure to Brazil, more specifically to São Paulo. So, it is possible to extend the comparison promoted by Heliana Salgueiro between Daumier and Porto Alegre also to Agostini, who had his formative years in a city dominated by the Charivari and undoubtedly came under the influence of the biggest and most popular satirical artist of the period.

It is, however, in São Paulo that Agostini started his career, five years after his arrival, launching the first satirical magazine of the city. Released in 1864, the Diabo Coxo (The Lame Devil) was a weekly newspaper that published articles by Luis Gama, an abolitionist journalist linked to the Liberal Party who was recognized, years later, as one of the great intellectuals of the anti-slavery cause. The partnership would also render a second pub-

BALABAN, Marcelo. Poeta do Lápis: A Trajetória de Ângelo Agostini no Brasil Imperial - São Paulo e Rio de Janeiro - 1864-1888. Campinas, 2005. Dissertation (Doctorate in History), Universidade Estadual de Campinas (Unicamp), p. 12 et seq.) points out that the construction of Agostini's image as "abolitionist hero" was a later product, caused by posthumous and laudatory equalization of the cartoonist with Joaquim Nabuco, who died in the same month. This deconstruction of the myth, however, does not invalidate the critical production against slavery that is verifiable in the work of Agostini, especially from the early 1880 s. lication, the Cabrião (Troublesome) in which the talents of Agostini became even more evident. Although both publications have had a brief life of only a year long, the noise they made in the São Paulo cultural scene was loud. Their opposition to the aristocratic elite and the clergy, as well as their criticism of the monarchical government, earned the artist several enemies and constant attacks against his publications. The corrosive characteristic of his brush did not disappear with time, and in his future work Agostini carried the sign of criticism to slavery ${ }^{9}$ and monarchy, as well as the fight against the clergy and the Church's policy in the country. His permanence in São Paulo turned out to be unsustainable after the discontinuation of 
10

In addition to Mosquito, Agostini drew for 0 Harlequin and Vida Fluminense in his early years in the capital. He was very successful, and his magazine Illustrada ended up being the most enduring satirical publication of the second half of the nineteenth century. (TELLES, Angela Cunha da Motta. Desenhando a Nação: revistas ilustradas do Rio de Janeiro e de Buenos Aires nas décadas de 1860-1870. Brasília: Fund. Alexandre de Gusmão, 2010. p. 43).

11

The construction of the memory of the genre guaranteed Agostini the paternity of Brazilian Comics, and with it, the tribute of naming one of the main awards of the ninth art, the Angelo Agostini Award, organized and awarded by the Association of Cartoonists of São Paulo. For more, see AUGUSTO, José Carlos. Um Provinciano na Corte - As Aventuras de "Nhô-Quim" e a Sociedade do Rio de Janeiro nos anos 1860-1870. São Paulo, 2008. Dissertation (Master in Social History), Universidade de São Paulo (USP).

12

More about Fleiuss in: NERY, Laura. Sentidos do humor: Henrique Fleiüss e as possibilidades de uma sátira bem-comportada. In: KNAUSS, P., VELLOSO, M. P., OLIVEIRA, C., MALTA, M. (Org.). Revistas llustradas. Modos de ler e ver no Segundo Reinado. Rio de Janeiro: Mauad X/Faperj, 2011. p. 173-187.

13

Even though Henry Fleiuss should only be considered a professional cartoonist with reservations, as the German from Köln was originally a printmaker and watercolor painter, he is the founder of the first long-life humoristic magazine in Brazil, the Semana Illustrada (Ilustrated Week, 1860-76), which became famous for its satirical drawings - but was not as politically corrosive as other magazines in the period, since it refused to criticize the government and in particular the emperor, as highlighted TEIXEIRA, Luíz Guilherme Sodré. 0 Traço como Texto - A História da Charge no Rio de Janeiro de 1860 a 1930. Rio de Janeiro: Edições Casa de Rui Barbosa, Coleção Papéis Avulsos n. 38. 2001.

14

TELLES, Angela Cunha da Motta. Desenhando a Nação: revistas ilustradas do Rio de Janeiro e de Buenos Aires nas décadas de 1860-1870. Brasília: Fund. Alexandre de Gusmão, 2010. p.38.

15

Agostini himself fed a rivalry with Fleiuss, especially when accused - by admirers of the German - of being his imitator. Thus, in the edition of October 24th 1868 of Vida Fluminense, Agostini starts a series titled Dr. Week Perturbations" (in reference to Mr. Week, a character created by Fleiuss), adding that they were Agostini's drawings, "not a copy from some German newspaper", directly criticizing the rival. the Cabrião. Agostini had to depart to Rio de Janeiro. In the capital, Agostini continued to be guided by his entrepreneurship. Publishing his cartoons in several publications, among which stood out The Mosquito ${ }^{10}$, the draftsman was able to establish and gain reputation. In 1869 he published As Aventuras de Nhô-Quim ou Impressões de uma Viagem à Corte (NhôQuim Adventures or Impressions of a Trip to the Court), a work in sequential art that is now considered the first comic book produced in Brazil ${ }^{11}$, and in 1876 he founded the Revista Illustrada (IIlustrated Magazine), which turned out to be his greatest achievement. Much of his work was published in this magazine, in which we can observe the evolution of the trait and the refinement of the satirical criticism of Agostini. Illustrada would be the means by which Agostini and his colleagues promoted opposition to monarchical government, and would also be one of the venues through which the population would follow the last years of slavery, the fall of the monarchy and the Republican ascendancy in the Brazilian political scene.

Agostini can be indicated, along with Henrique Fleiuss ${ }^{12}$, as the first professional cartoonist in Brazil ${ }^{13}$, having worked with satirical cartoons all his life. This "double paternity" of the genre in Brazilian lands - of French descent - in no way diminishes Agostini's work; on the contrary, if Porto Alegre was the first author-cartoonist, Agostini was one of the most important promoters of satirical drawing in the nineteenth century. He was also the most entrepreneurial, and no doubt, the most responsible for the flourishing and expansion of the art of cartoons in the country. He founded some of the best known satirical publications in the history of the genre in Brazil, and his drawings closely followed the major political events of the second half of the nineteenth century, placing Agostini in a privileged position not only in the chronicle of events but also in shaping the worldview of the population, especially in Rio de Janeiro and Sao Paulo, where his work had greater acceptance and penetration.

The cartoonist and his role in the production and dissemination of worldviews The Agostini case gives us the opportunity to briefly discuss the role of the cartoonist in the Brazilian nineteenth-century society, especially in São Paulo and Rio de Janeiro. There is no doubt about the popularity of the genre at the time. After the first experience of Porto Alegre, there was a large number of illustrated humor magazines throughout the country, with special emphasis in the city Rio de Janeiro. The genre had a boom in publications in the 1860s and 1870s, appearing only in the capital, among others, the magazines Semana Illustrada, Bazar Volante, O Arlequim, A Vida Fluminense, Fígaro, O Ba-ta-clan, O Mosquito, Revista Illustrada, O Mequetrefe, A Comédia Social, O Mephistopheles, O Mundo da Lua, O Psit!, and O Besouro. ${ }^{14}$

This great variety of titles also leads to a certain fragmentation of the reading public. It is natural that distinct preferences arise, reaching the brink of feuds between readers (or artists ${ }^{15}$ ) of rival magazines. In the same way, most of the publications that criticized the imperial government, such as Agostini's Revista Illustrada, tended to attract a different audience than that of Semana Illustrada, where Fleiuss cultivated a respectful deference to the regime and the emperor's figure. The grouping of readers by affinities with the ideological and redaction lines of publications observed in Brazil in the nineteenth century lies at the heart of the development of the national press and the composition of a public arena of social and political debates. If the bringing of Royal Press and the publication of Gazeta do Rio 
There is a caveat concerning the place of production: the Correio Brasiliense may be considered the first Brazilian newspaper, but it was published monthly in London (not In Brazil) by Hipólito da Costa between, March 1808 and December 1822. (MELO, José Marques de. História Social da Imprensa. Porto Alegre: EDIPUCRS, 2003. p. 90).

17

The Census of 1879 and 1890 clearly demonstrated it: in the first one, the illiteracy rate among Brazilians over five years old was $82.3 \%$, while the 1890 one showed a rate of 82.6\%. (HOLLANDA, Sérgio Buarque de. História Geral da Civilização Brasileira, t. II: 0 Brasil Monárquico, $5^{\circ}$. vol. Do Império à República. Rio de Janeiro, São Paulo: DIFEL, 1977. p. 188).

18

SODRÉ, Nelson Werneck. História da Imprensa no Brasil. Rio de Janeiro: Civilização Brasileira, 1966. p. 240

BOHNSACK, Ralf. Qualitative Bild- und Videointerpretation. Opladen: Budrich, 2009.

20

BOURDIEU, Pierre. Le Sens pratique. Paris: Les Éditions de Minuit, 1980. de Janeiro (both in 1808) are considered the initial milestones of Brazilian press $^{16}$, it is the Second Empire (1840-1889) that the press is fully developed, reaching maturity after its first decades. It's the period when groups of readers would be consolidated, and these discordant opinions would promote the consolidation of what could be called public opinion.

Largely, the press developed thanks to the freedom that Emperor D. Pedro II granted to newspapers and magazines of the period. It is in this time that the illustrated satirical press reached its height, dealing with all kinds of subjects and spreading opinions and criticism. The cartoonists and artists who published their drawings have become opinion leaders in a sense hitherto never seen in the country. The popularity of their cartoons guarantees the penetration of their ideas in society, and the representations disseminated by their work quickly became a part of the imaginary of the time. The fact that they refer to essentially pictorial elements gives the cartoons a unique importance in society, as they included in the debate, to some extent, the uneducated and illiterate, a considerable ${ }^{17}$ part of society during the Second Empire. On the subject, Joaquim Nabuco declared that Revista IIlustrada was the "bible on abolition for those who could not read".18

With the emergence of this public opinion and the growing importance that the cartoonists earned in this context, the analysis of his drawings gains even greater importance in studies on the political culture of the period. The nature of his productions deserves thus considerations and digressions that problematize his work.

We are thus guided by the principle proposed by Bohnsack ${ }^{19}$ on the construction i.e. production of the image. According to the German sociologist (who takes photos as a privileged case), the main point of reflecting about the nature of the images lies in differentiating the representing picture producer from the represented producer (abbildende und abgebildende Bildproduzenten) and their corresponding habitus (in the sense of Bourdieu ${ }^{20}$ ), taking both as active agents of the composition. Specifically in the case of photographs (as well as in the case of documentary videos), this difference can be readily perceived as the representing producer's habitus is revealed in the composition and choices made during and after the act of image production, while a sample of the represented producer's habitus can be apprehended in the product itself, in the depicted scene. As Bohnsack points out, the habitus can be in harmony (in case both producers, represented and representing, come from the same milieu) or conflict (when they come from different environments), but both are recognizable. At this point, cartoons present a drawback.

The role of the represented producer, in cartoons, ceases to be an "objective" role, i.e. of a real and present model that "self-portrays" himself and his habitus, and becomes a "subjective" role. In the case of objective models, there is a real interaction between representing and represented producers in the moment of production, and the actions of both influence and are consistently represented in the final composition of the image. In the case of cartoons, the represented producers' habitus is the result of an interpretation of their ideas and their actions by the cartoonist. This applies both to cartoons that represent real individuals, i.e. politicians or prominent social actors, as well as to those that portray institutional elements or archetypal characters that symbolize a particular class, party or ideal. Whether the represented producer exists in material reality or whether it is a fictitious or symbolic character, the habitus and the world- 
21

MANNHEIM, Karl. Wissenssoziologie - Auswahl aus dem Werk. Berlin / Neuwied: Luchterhand, 1964.

22

Entre outros, ACCARDO, Alain et.al. Journalistes au quotidien - Outils pour une socioanalyse des pratiques journalistes. Bordeaux: Le Mascaret, 1995 e LIEBEL, Vinícius. Politische Karikaturen und die Grenzen des Humors und der Gewalt - eine dokumentarische Analyse de nationalsozialistischen Zeitung Der Stürmer. Opladen: Budrich Unipress, 2011.

TEIXEIRA, Luiz Guilherme Sodré. O Traço como Texto - A História da Charge no Rio de Janeiro de 1860 a 1930. Rio de Janeiro: Edições Casa de Rui Barbosa, Coleção Papéis Avulsos n. 38. 2001. p. 51.

BALABAN, Marcelo. Poeta do Lápis: A Trajetória de Ângelo Agostini no Brasil Imperial - São Paulo e Rio de Janeiro - 1864-1888. Campinas, 2005. Dissertation (Doctorate in History), Universidade Estadual de Campinas (Unicamp). p. 49. view that he will represent in the cartoon scene will always be an interpretation by the representing producer, a product of the cartoonist's mind.

The opinionative character of the cartoon reveals this definition, and through this opinionated representation - whether complimentary or critical - based on a humorous and/or violent speech, the cartoonist presents his judgement. In the process of production of the cartoon, the role of the represented producer can still be considered a mixture between subjective and objective, as the image may present real actors/persons promoting actions that were also performed in reality. The form of representation, the speech, the direction that humor or violence imposes in the scenic composition of the cartoon, as well as the use of narrative metaphors, reveal the cartoonist's perception about the event or the represented character. This role on which the cartoonist is invested, the great whistleblower, is the key to the analysis of a more tenuous field. While the cartoonist allegedly acts as the boy who points to the monarch and denounces: "the king is naked!", he ends up revealing broader dispositions than his mere opinion. He reveals structures of thinking that (re)produce themselves in a subtle way, constituting a modus operandi of thinking, a worldview (Weltanschauung) in the sense of Mannheim ${ }^{21}$ which presents and reinforces itself through the pictorial representation.

This worldview expressed in cartoons certainly needs to be problematized, especially when we think of cartoonists working for large media conglomerates or in modern commercial newspapers. This discussion was already brought up in other works ${ }^{22}$ and presents the cartoonist, as well as journalists, wrapped in a normative habitus of the company (newspaper) in which he works, a habitus that is conducted by material and political interests of the company and its directors. However, the case of Brazilian nineteenth century illustrated magazines, and even more specifically the case of Angelo Agostini, has an even more direct relationship between the worldview of the cartoonist and the interests of the publication. This is because the magazines were to some extent out of the market logic, which raised the personalization of the trace and the message it carried. As pointed by Teixeira ${ }^{23}$, much of the magazines (although not all of them, as the presence of advertisements on the pages of some of them shows) did not depend on financial returns to exist. Being characterized by an almost amateur administration, they did not seek profit, but "merely" survival. They were conceived as a means of communication and dialogue, in an almost romantic foundation of a discussion arena, of a public opinion that was aimed primarily at the political, economic and cultural elite. Their reach, however, cannot be restricted to that elite, for reasons already herein. Indeed, in many cases, the satirical magazines tried to establish a connection between the elite and other social strata, translating other realities to those at the top of the pyramid and also making themselves attractive to some readers from its base.

This incipient public arena, in which the illustrated magazines were some of the pioneer actors, opens space for cartoonists to appear as opinion leaders. According to Balaban ${ }^{24}$, "The press would have a most important function, not only for translating ideas in a simpler way, for indoctrinating without making the reader think, but above all for achieving a large contingent of souls". Hence the importance of the analysis of mental structures that are evident in the images, the way they present themselves and their ways of action. This approach on the study of cartoons enables a 
25

WELLER, W. "A contribuição de Karl Mannheim para a pesquisa qualitativa: aspectos teóricos e metodológicos." In: Sociologias. N. 13. Porto Alegre. Jan-Jun. 2005; WELLER, Wivian. Minha Voz é tudo que eu tenho. 2011 and WELLER, Wivian; MALHEIROS DA SILVA, Catarina. Documentary Method and Participatory Research: Some Interfaces. In: International Journal of Action Research. 7 (2011), 3, pp 294-318.

26

BOHNSACK, Ralf. Rekonstruktive

Sozialforschung. Opladen: Budrich, 2007 BOHNSACK, Ralf. Qualitative Bild- und Videointerpretation. Opladen: Budrich, 2009.

27

LIEBEL, Vinicius. Politische Karikatur und die Grenzen des Humors und der Gewalt. Opladen: Budrich Unipress, 2011; LIEBEL, Vinícius. Entre Sentidos e Interpretações: apontamentos sobre a análise documentária de imagens. In: ETD Educação Temática Digital. Campinas, v. 12, n. 2, 2011b. p. 172-189.

28

WELLER, Wivian; PFAFF, Nicole. Metodologias da Pesquisa Qualitativa em Educação. Petrópolis: Vozes, 2010.

29

BOHNSACK, Ralf. Qualitative Bild- und

Videointerpretation. Opladen: Budrich, 2009. p. 158.

30

For an example of such a description, which is taken here as a model, see LIEBEL, Vinicius. Entre Sentidos e Interpretações: apontamentos sobre a análise documentária de imagens. In: ETD Educação Temática Digital. Campinas, v. 12, n. 2, 2011b. p. 172-189.

31

With the valuable exception of PEREIRA, Washington Kuklinski. O Traço e a Pena - A Campanha Abolicionista de Ângelo Agostini na Revista Illustrada (1884-1888). São Paulo, 2010. Dissertation (Master in Social History), Pontifícia Universidade Católica de São Paulo (PUC-SP). privileged access to a subtle field of society (or to the social group that the cartoonist and his magazine represent and, to some degree, delimit) that helps not only to understand the general structures that guide them, but also the ways and forms of reproduction and maintenance of these structures.

\section{The Analysis and Reconstruction of Cartoons - Agostini on two case studies} The methodology proposed here is based on the documentary method, conceived by Ralf Bohnsack. The bases of the documentary method in its general form can be found in the works of Wivian Weller ${ }^{25}$ and Ralf Bohnsack $^{26}$, and specifically on the analysis of cartoons, by Vinícius Liebel ${ }^{27}$. A broader overview is presented in the book organized by Wivian Weller and Nicole Pfaff 28

In short, the documentary method advocates the transposition of the inherent (literal) meaning to the documentary meaning of the images, i.e. "changing the questions on what are the cultural and social phenomena and realities for the question on how it was produced". ${ }^{29}$ Bohnsack suggests that the way to reach such an outcome is fundamentally based on Panofsky's iconographic and iconological analysis, and Imdahl's iconic method. The aim is to achieve a broad understanding of the greatest possible number of imagistic levels that comprise the source, as well as its relation to the context of production, going from the analysis about (über) the source to an analysis through (durch) it. To this end, we split the analysis into four steps: pre-iconographic and iconographic analysis, which would make the formulating interpretation, and the technical and structural analysis together with the iconological-iconic interpretation, forming the reflecting interpretation. The following analysis of two cartoons by Agostini will be condensed and will not bring a detailed description of these stages ${ }^{30}$, but will follow the principles of the method and will raise the relevant issues that it favors.

The analyzed images were produced by Agostini between 1870 and 1885. Both, therefore, were produced before the abolition of slavery in 1888, and make explicit references to this subject. A recurring theme in Agostini's work, the situation of slaves in Brazil, is explicitly represented by the cartoonist, and so the artist assumes his abolitionist activism through these cartoons. It is a still a superficially explored subject ${ }^{31}$ and which deserves a detailed study to examine the main features of the drawings, to point Agostini's strategies of militancy and to check the possible existence of variations in the visual and discursive elements over the years, as well as the possibility of recognizing "phases" in his production, marked by themes or by different aesthetic factors. The analyses that follow are not intended to be a categorical study on Agostini, not even a definitive study on the subject of slavery in his work. It is an exercise in interpretation that seeks to identify relevant questions about the images analyzed here, which were selected for their representation amid the cartoons with the abolitionist theme produced by Agostini. It's also a meditation on the interpretation of pictorial sources by historians. 


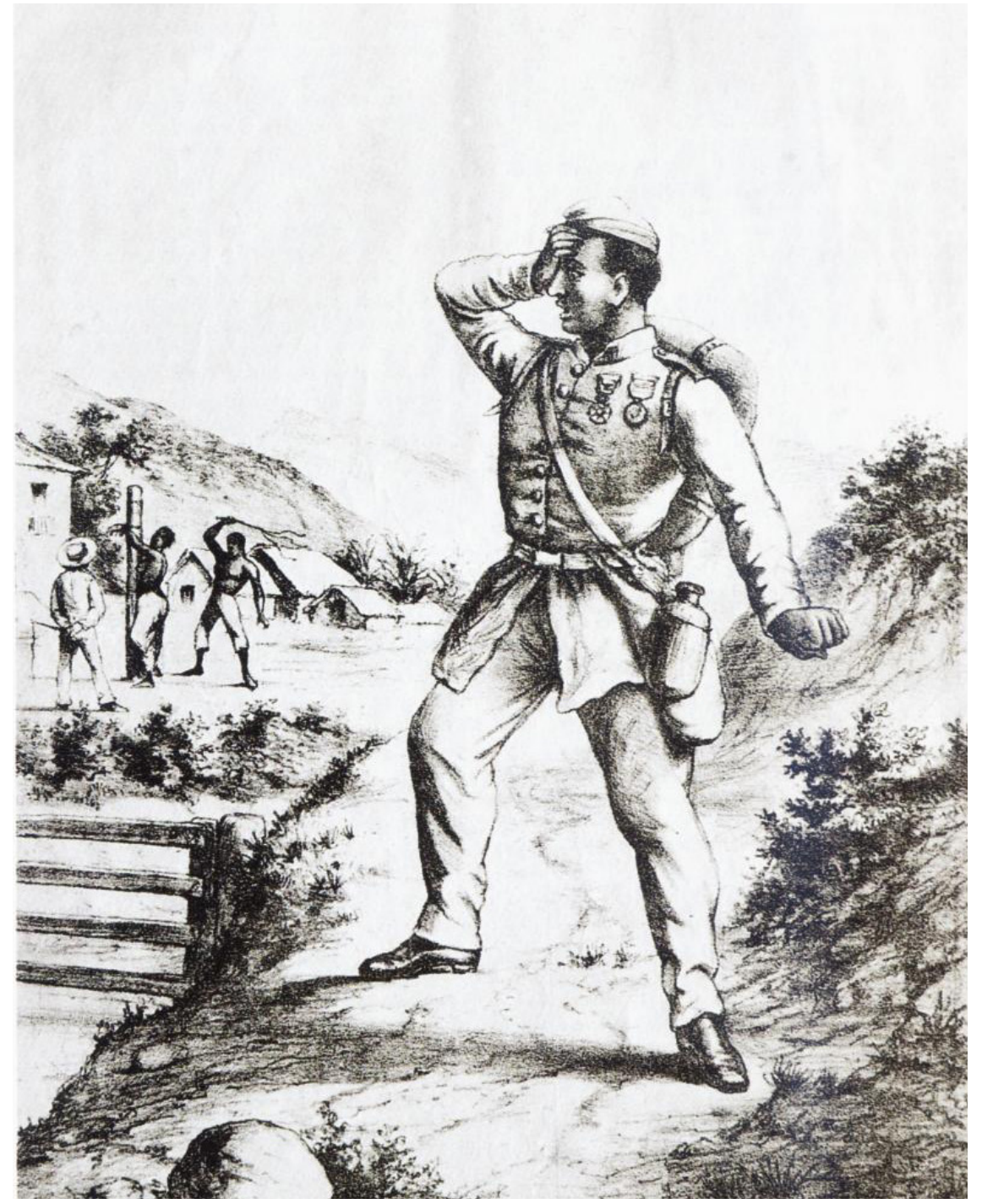

Image 2 - AGOSTINI, Ângelo. De Volta do Paraguai. In: Revista Vida Fluminense. Rio de Janeiro, №. 12, jun. 1870.

The image above, published in the newspaper Vida Fluminense in 1870, has as its central theme, as its title suggests, the return of Brazilian soldiers from the Paraguayan War (1864-1870). In its composition, we can observe a rural scene, i.e. a farm, surrounded by undergrowth and a large empty space. Near a mountain and a few trees, five houses complete the image's background. In the middle ground, a group of three people stays in front of the houses: one person wears a jacket, pants and hat and holds a whip in his hands; a woman in white pants is tied in a trunk with her arms to the air and her back turned to the third one, also in white pants and with a whip in his right hand, which, by performativity and scenic construction, accuses the flogging of the second. The latter two are black, while the first is white.

There is a fourth character, also black and highlighted in the foreground, which seems to observe the scene on the intermediate plane. He wears a military uniform, carries a backpack as well as a canteen and a knapsack. Also noteworthy are the two medals that are hanging on his chest. His expression denotes surprise and amazement, as evidenced not only by the hand on the forehead, but also by his open mouth and wide open eyes. His body language as a whole denotes stiffness, the position of his feet even suggests a preparation for combat, which is reinforced by the clenched fist, 
but is contradicted by his facial expression. In addition, this rigid position and possible preparation for a clash occurs while the character has the body practically facing the direction opposite to the scene, which means his back is facing the intermediate plane, as his face turns to it. This set of expressive elements is in opposition to the body language of the element with a jacket on the intermediate level, which denotes peace and naturalness.

The scene at the center is clearly recognized as a punishment of an African slave carried by a feitor (chief factor), also African, under the watchful eyes of his master. The body language of the slave owner, more than tranquility, shows a position of power, a power of management, of the chief observing his subordinates (the feitor) while they carry out their tasks. The performativity of the feitor, through the projection of his action and the position of the arms, denotes strength and attack, denouncing the violence of the scene. This violence is then perpetrated against the tied female slave, who is defenseless.

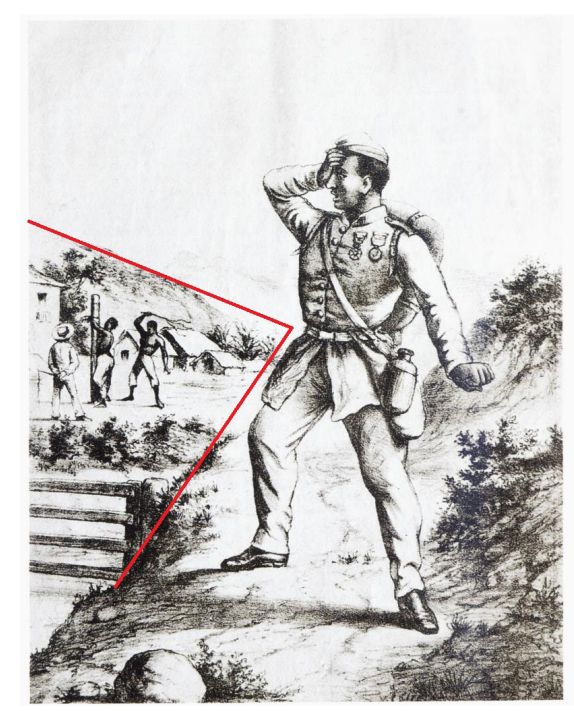

Image 3

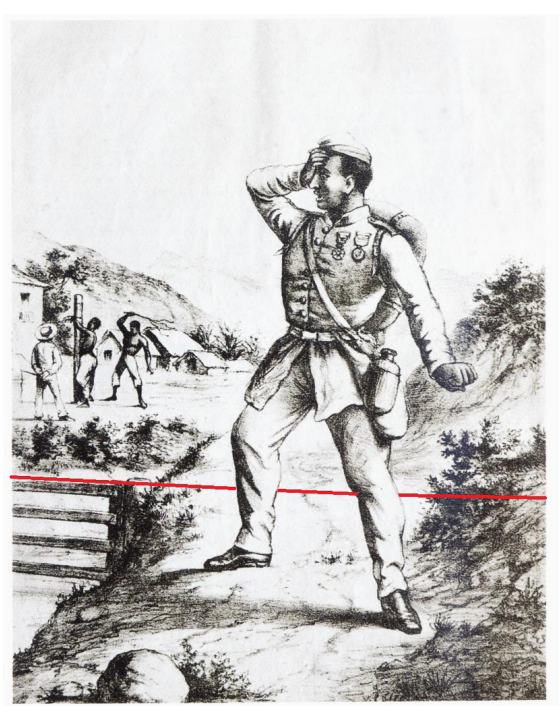

Image 4

By observing the planimetric composition and the framing, it is possible to trace a line that follows the outline of the mountain and the outline of the grass which borders the gate, as Image 3 shows. These lines end up defining a specific area of the image, the scene that takes place in the intermediary ground, i.e. the lash of the slave. This delimitation is not only to frame the scene in the landscape, but also to differentiate spaces, distinguishing between the characters of the primary and the intermediate plans beyond its geographic-spatial place in the whole composition.

This division is reinforced by the line that can be drawn from the upper edge of the gate (Figure 4), establishing a line that cuts the image in half and determines a new "frontier" in the composition. Through it, we can see that the gate and the line are located "behind" the soldier, determining that he is outside the geographical boundaries of the farm. Still, it is possible to observe that the top of the gate is in the same level of the space on which the soldier stands, allowing the delimitation of two spaces. Again, the soldier is put out of the limits of action, in a different plane and a different environment.

Such demarcation, however, is contradicted by a further analysis. The soldier is not in front of the gate, which would certainly keep him from getting to the place where the action occurs (and perhaps do something against 
SILVEIRA, Mauro César. A Batalha de Papel - a charge como arma na guerra do Paraguai. Florianópolis: Ed. UFSC, 2009. p. 162.

33

Mauro César Silveira (A Batalha de Papel - a charge como arma na guerra do Paraguai. Florianópolis: Ed. UFSC, 2009. p. 161) makes a summary of this debate and shows that the projections contain variations that comprise the view of Júlio José Chiavenatto $(0$ Negro no Brasil. São Paulo: Brasiliense, 1986), who estimates the number of Afro-Brazilian killed in action between 60 and 100 thousand, the study by Paulo de Queiroz Duarte (Os Voluntários da Pátria na Guerra do Paraguai. Rio de Janeiro: Bibliex, 1981), who counts less than 8.500 black soldiers in Brazilian Army, and Ricardo Salles (Guerra do Paraguai - escravidão e cidadania na formação do exército. São Paulo: Paz e Terra, 1990), who estimates that the portion of AfroBrazilian soldiers in the imperial Army was hardly bigger than $10 \%$.

34

IMDAHL, Max. Giotto Arenafresken: Ikonographie - Ikonologie - Ikonik. München: Fink, 1996. p. 107. it). The soldier is on the same plane of the land where the action takes place, and no physical impediments or obstacles separate them. This contradiction between the planimetric composition, the conditions it imposes on the organization of the scene and the potential agency of the soldier (seen in projection) seems to report an inherent disability of the soldier regarding the protest against the scourge. This is not due to any soldier's incapacity - his medals show, in theory, his ability to act and maybe also his bravery. In the image, however, he does nothing besides showing his outrage.

By analyzing the image in its context of production, it is easy to see the reference to the situation of Brazilian slave soldiers, part of "Motherland Volunteers" (Voluntários da Pátria), who had just returned to the country as free men. The policy of the Empire in this case was to accept and even encourage the recruitment of slaves into the Army's ranks in exchange for financial compensation to the slave owner. A policy of "blind eyes" regarding the escaped slaves who enlisted was also evident. ${ }^{32}$ Despite the fact that the Afro-Brazilian portion of the army is still subject of historiographical debate ${ }^{33}$, it surely wasn't a negligible number, and their return caused a noticeable change in the dynamics of imperial society. In addition, there was a discrepancy between the roles of "heroes of the motherland" and that of "slaves", as well as an apparent incongruity of the perception of social and political perspectives that opened onto the black portion of the population in Brazilian cities.

The analyzed image is consistent with that moment and the reflections it engendered. In an iconological perspective, the main character stands out not only for being a military man, but mostly for being a black soldier. The performativity in the scenic constitution shows indignation, but from the above considerations, the outrage is guided not only by the violence exhibited, but mainly by an apparent (and sudden) awareness of the value and dignity of black men. The value of freedom, for which the soldier would have fought in a foreign country, finds an apparently insurmountable resistance in his own land. Along those lines, the same black man who had fought in the Paraguayan War and who was worthy to wear the national uniform seemed to be unworthy of being free, and the permanence of the institution of slavery seems, in the eyes of the represented soldier, though illogical, inevitable .

The perception of this inevitability is perhaps the invisible element that prevents the soldier from interfering with the scene. As Image 3 clarifies, there is no physical impediment to the character. The terrain limitations and boundaries that are raised are imaginary, resulted of the line projections from the gate on. More than a real impediment, the image reveals a supposed habitus of conformity, a modus operandi of the newly returned slaves' actions, who do not get to struggle for the abolitionist cause. Yet, the rigid pose preparing for the fight that was described in the first paragraphs of this analysis is held with the soldier's body turned away from the scene, therefore fruitless.

The subtle theme of this picture is the inaction of Afro-Brazilians, which complements the central focus, indignation, characterized by the stiffness of the soldier's posture. This apparent contradiction in the global apprehension of the image, from an action (and a potential action) driven by indignation to the inaction caused by an alleged habitus of conformity (and complemented by the presentation of the ineffectiveness of the soldier's posture) may be classified, in words of Max Imdah| ${ }^{34}$, as a complexity of meaning of transcontrariety (Sinnkomplexität des Übergegensätzlichen), a dimension of meaning that is not revealed as the primary concern of the image and depends on a 
"Cheio de glória, coberto de louros, depois de ter derramado seu sangue em defesa da pátria e libertado um povo da escravidão, o voluntário volta a seu pais natal para ver sua mãe amarrada a um tronco. Horrivel realidade". cross perception of its founding dichotomy to be defined. Thus, the expressive sense is redefined when the image is reconstructed, when its documentary sense is reached. The dichotomy that lies between the expressive meaning and the documentary composition, i.e. the result of the analysis of the performativity in conjunction with the planimetric and scenic reconstructions of the image, form the basis for the comprehension of this complexity of meaning, which ultimately lead us to a new apprehension of the source.

The cartoon discussed above still brought, when published, some textual elements outside the framework of the image. In addition to the aforementioned title, "Back from Paraguay," a caption accompanying the picture with the words "Full of glory, covered with laurels, having shed their blood in defense of the homeland and freed a people from slavery, the voluntary returns to his country to see his mother tied to a log. A horrible reality." ${ }^{135}$ The analysis of the text, together with the image, identifies three main points. The first is a confirmation of the iconographic-iconological analysis, particularly the temporal location of the scene as immediately after the Paraguayan War and the characterization of the "valour" of the soldier. The second point is the confirmation of the incongruity between the soldier's fighting in Paraguayan territory (according to the caption, against the oppression and slavery) and the persistence of slavery and oppression in Brazil. The third point to be raised is the identification of the character tied to the log, the mother of the soldier. This finding raises the documentary interpretation to a new level, since the reaction of the soldier on the scene no longer refers "only" to an injustice against a human being or even against a member of the same "racial" group; the caption identify the victim as a member of the soldier's family. The blood-bond that unites the two characters ends up giving a new tone for the soldier's expression of indignation - but also gives greater importance to the interpretation of inaction, crediting even more weight to the structures of thought and action attributed to the soldier (and to Afro-Brazilians in general) by the cartoonist.

\section{Image 5: Black and Yellow}

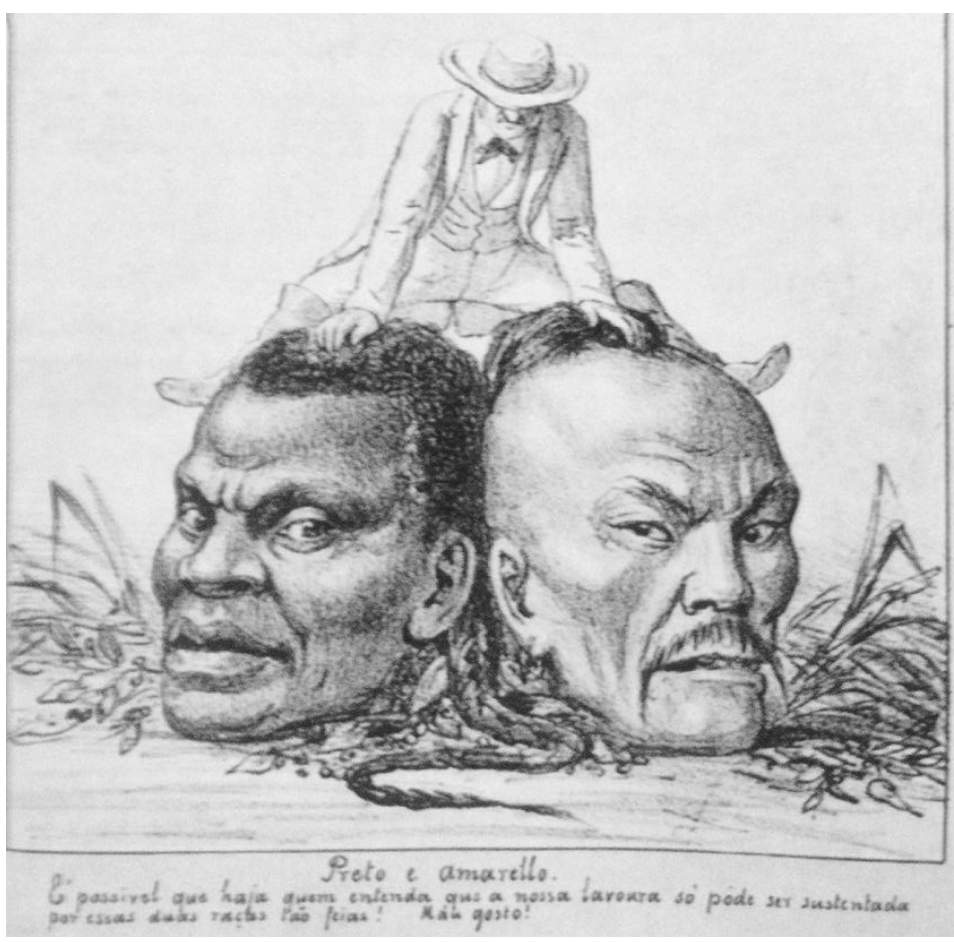

Image 5. AGOSTINI, Ângelo. Preto e Amarello. In: Revista Illustrada. Rio de Janeiro, № 258, jul. 1881. 
The second selected image is less complex than the first, especially regarding its details and content. A group of three characters is in the center of the cartoon; an African, an Asian and a Caucasian. The first two are represented only by their heads, in complete disproportion when compared to the Caucasian. The last one does not show his eyes, using a hat to cover them, but he lies above the two heads, "climbing" them. Among his garments, besides the hat and the bow tie, his suit and boots stand out. As for the other two elements, both seem to look towards the viewer/reader, with some signs (or wrinkles) on the forehead and between the eyebrows. The African has short hair, while the Asian has a "Chinese" mustache, i.e. a mustache that extends at the ends and runs down until the chin, and long hair, arranged in a braid, extending over the floor. The surroundings of the scene consist of grass vegetation. In the iconographic level, the representation of large heads fulfills a specific function. Their disproportion with the Caucasian element, before representing some form of superiority, serves as the archetypal representation for the two "races", namely, the Black/African and Chinese/Asian. As for the third element, his clothes denote a high economic status, but the details that complement the aesthetic composition of the character, particularly his hat and boots, accuse the specificity of the figure and characterize him as an aristocratic farmer.

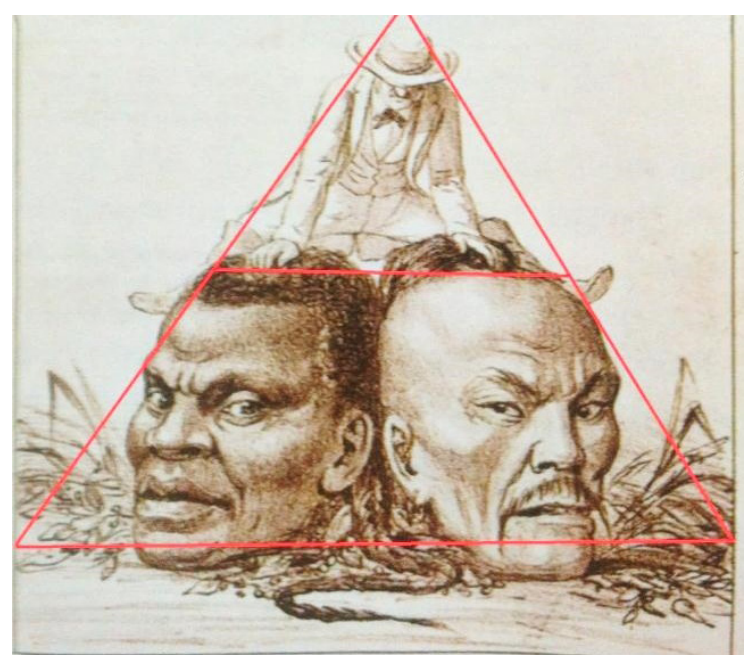

Image 6

The image is organized in a pyramidal shape, composing a simple and planimetric panel. In fact, in addition to the characterization of a single frontal plane, i.e. without background, the image only allows for the observation of the spatial conformation of the three elements, the two heads being, namely the African and the Asian, side by side at the base of the structure. The Caucasian, on the other hand, stands over the two heads, occupying a position on a higher plane than the other two.

The analysis of the picture in its own historical context allows the interpretation of the characters in terms of economic structure and power. The two heads, representing African and Asian ethnic groups are, symbolically, in the bottom of the labor pyramid in imperial Brazil. It is a direct reference to slave and immigrant labor employed in the agrarian industry. The characterization of the Caucasian on the ridge of the pyramidal structure can also be seen in a new light not only when the context of production is taken into account, but also when taking into consideration the cartoonist's work. In fact, the jacket, the boots and the hat help composing 
36

NABUCO, Joaquim. "O Mandato da Raça Negra." In: CARNEIRO, Edison (org.). Antologia do Negro Brasileiro. Rio de Janeiro: Agir, 2005. p. 23-27. p. 24.

37

Although it is not the focus of this paper, it must be emphasized that this slow political and legal process was in no way the only variable in question. In addition to the maturing of the abolitionist movement, the resistance of the slaves dating back to decades before 1888 , and the various quilombos, there are some of the vectors of this context that transformed social relations and shaped the urban and rural landscapes. Among the vast bibliography on the subject, it can be highlighted here the works of Hebe Matos (Das Cores do Silêncio. Rio de Janeiro: Nova Fronteira, 1998.) Maria Helena Pereira Toledo Machado (Crime e Escravidão trabalho, luta e resistência nas lavouras paulistas 1830-1888. São Paulo: Brasiliense, 1987 e From Slave Rebels to Strikebreakers: The Quilombo of Jabaquara and the Problem of Citizenship in Late-Nineteenth-Century Brazil. In: The Hispanic American Historical Review, Estados Unidos, v. 86, n. 2, 2006. p. 247-274), Seymour Drescher (Abolição - Uma História da Escravidão e do Escravismo. São Paulo: Unesp, 2011.), Celia Maria Marinho de Azevedo (Anti-racismo e seus Paradoxos. São Paulo: Annablume, 2004) and Eduardo Silva (As Camélias do Leblon. São Paulo: Cia das Letras, 2004.).

38

SMITH, Woodruff D. The Ideological Origins of Nazi Imperialism. Oxford: Oxford University Press, 1989. a very specific type in the representations of Agostini, as it can be seen through the comparison with the previous image. It is the representation of a farmer and slave master, which ends up having direct repercussions in relation to the Brazilian imaginary of the period. Previously synonymous of good political and social condition, the figure of the slaveholder is transformed in representations such as Agostini's, which makes it synonymous to cruelty and irrationality.

The image of the aristocratic slaveholder undergoes a change in the collective perception. Its basic subjective essence leaves behind the respectability that social position could give. In fact, the new sociability, the emergence of an urban middle class, and the new historical moment opened with the independence brought up a series of debates, concepts, and political and social meanings that provide new insights on many issues, such as labor relations, citizenship and freedom. In this process, the popularization of the press in general (and the illustrated press in particular) had an active role. If the written press talks, in theory, to reason, the illustrated press deals primarily with subjectivities. Changes in perceptions and in the imaginary advance with and through it, as the representation of the slaveholder shows: the slave master of the Second Brazilian Empire is no longer the slave master of the Portuguese colony.

This imaginary structure of society is the field where Agostini and his cartoons will act both as producers and propagators, and it reinforces of worldviews. The engagement of Agostini's drawings makes this dynamics even more evident. In the drawing above, this is verifiable by the use of the slave master's figure, which becomes a sign (carrying a number of inherent negative qualities) in the Agostinian representations. The cartoon acts in denunciation through the representation of the aristocrat "riding" on the two heads, which denotes the exploration of his action. However, at the same time, the cartoon shows a "higher" position of the white man when compared with the other two elements. Indeed, there is a double meaning in the image that seems to point out the injustice of the situation, but also to reinforce the idea of domination; especially because there is nothing in the scene that can stop it (no resistance from the African and Asian is conceivable, since they even have limbs and bodies to defend themselves).

This apparent contradiction does not differ from the observable logic in context. It can be found in what represented part of the Brazilian liberal thought in the last decades of the empire, which blended the unshakable principle of private property with an "anti-slavery and anti-racism (but not abolitionist) facet." This places the issue of abolition in the center of political discussions, contrary to what occurred in European countries, as described by Joaquim Nabuco ${ }^{36}$, where abolitionism was primarily seen as a religious and philanthropic question. In Brazil, the slow political and legal process leading up to the 1888 abolition avoided as much as possible to break with the idea of slaves regarded essentially as property ${ }^{37}$. Yet, without slavery, the public debate was focused on the means to supply the demand for labor force. One of these options was the incentive of immigration, which will be fully explored from 1850 on, but especially after the end of the slave trade. Europeans appear as the main alternative, providing an international need for unburdening the big European metropolises, who suffered with the modernization and large rural-urban migration ${ }^{38}$, and a national need, which in addition to the labor supply, would bring a further whitening of the national population, an idea defended by part of the elite 

contada: negro, racismo e branqueamento em São Paulo no pós-abolição. São Paulo: Senac, 2003. p. 253 et seq.

40

DEZIM, Rogério. Matizes do Amarelo - elementos formadores do imaginário sobre o japonêns no Brasil. São Paulo: Arquivo Público do Estado de São Paulo. Disponivel em : <http://www.usp.br/ proin/download/artigo/artigo_matizes_amarelo. pdf $>$ [acessado em 10 abr. 2013]. p. 2.

41

É possivel que haja quem entenda que a nossa lavoura só pode ser sustentada por essas duas raças tão feias! Mau gosto!

42

It is also necessary to contextualize Agostini's racism recalling the debates on the racial thematic involving intellectuals like Louis Couty and Silvio Romero. For more about it, see SCHWARCZ, Lilia Moniz. Retrato em Branco e Negro - Jornais, Escravos e Cidadãos em São Paulo no final do século XIX. São Paulo: Círculo do Livro, 1989; e SKIDMORE, Thomas. Preto no Branco: Raça e Nacionalidade no Pensamento Brasileiro. Rio de Janeiro: Paz e Terra, 1976.

43

LIMA, Herman. A Escravidão e a Monarquia. In: História da Caricatura no Brasil. v. 01. Rio de Janeiro: José Olympio, 1963. p. 208. that would have its peak in the early years of the twentieth century ${ }^{39}$. However, in the early stages of the immigration process, an alternative to Europeans was defended by good part of the political and economic elite, as described by Dezim:

\begin{abstract}
The end of the slave trade (1850), later associated with the abolitionist and imigrantist movement and with the coffee boom in the state of São Paulo, led to debates at city halls, congresses and even in the Senate about who should replace the "almost dead" African slavery. From historical, prejudiced and racist arguments, the imperial agrarian oligarchies chose to discard the black labor (synonymous to backwardness) and the national worker (synonymous to laziness), deciding to bring, as a transition element, Chinese or simply chim immigrant, considered by farmers a cheap and docile element when compared to European immigrant. ${ }^{40}$
\end{abstract}

Agostini's cartoon shows the two preferred options in this context (along with the option of domestic labor) being dominated by the farmer. The cartoon is also a representation of the idea of superiority of the white element in society, a current idea at the time. The interpretation of the image changes, however, with the insertion of the text elements in the analysis.

The cartoon, titled "Black and Yellow" in direct allusion to the two elements of the base of the pyramid, is complemented by the caption: "There are those who understand that our agriculture can only be sustained by these two ugly races! What a bad taste!"41 The use of irony in the caption guides the reader in another direction; what was previously perceived as a representation of domination turns into a criticism of the available choices. This criticism is revealed in two levels: the first is the convenience for the dominant white race towards work, as blacks are enslaved and the Chinese are "imported" to do the job whites themselves could do. The second level reveals the cartoonist aesthetically favors the whites in depreciation of the other two elements. Agostini's cartoons show thus a more complex side of his activism: an abolitionist and anti-slavery facet, but also with traces of racism ${ }^{42}$.

\section{Comparative Analysis and Conclusion}

The exercise performed here sought to make a brief reconstruction of the origins and early days of Brazilian illustrated press, reaching its primary focus, the cartoonist Ângelo Agostini. In Agostini we certainly find the maturing of the genre in Brazil, but also the formation of an illustrated militancy amid a public opinion that was being formed in the period of the Second Empire. Seeking to verify the ways in which this militancy was manifested, it promoted the analysis of two single images with main themes that gravitated around the subject of more passionate advocacy by Agostini: the abolitionism.

The analysis of the two images, previously selected amid the extensive work of Agostini, showed two examples of ways by which the cartoonist brought up the abolitionism theme. The first, which shows the soldier having recently returned from the Paraguayan War, uses the planimetric building to highlight the issue. There is no doubt that Herman Lima, commenting on this charge, got it right by stating that Agostini's drawings were some of the main weapons of the opposition to the monarchy, especially acting "towards the liberation of blacks." ${ }^{43}$ However, some elements of his drawings show peculiar characteristics of his thought. The planimetric and scenic construction of the first cartoon, for example, points to the central character's inability to take an attitude towards the flogging of his 
44

MARINGONI, Gilberto. Ângelo Agostini ou impressões de uma viagem da Corte à Capital Federal ('864-1910). São Paulo, 2006. Tese (Doutorado em História Social), Universidade de São Paulo (USP). p. 241 et seq.

45

Although exceptions, the images of the riots fulfill a specific role at the height of the abolitionist movement, pointing to a warning imaginary and predicting a possible scenario, if the issue were not properly handled. The following image (Figure 7) is an example of this dynamic. own mother, even though he has the path clear. The second image, in a similar way, uses spatial composition to show, by overlapping elements, an apparent immutable power ratio in which the black component is depicted as unable to withstand the white domain element.

The mental structures that trespass the images in their composition come to light through their analytical reconstruction. These structures show a level of understanding of the black element a little deeper than the one proclaimed by the abolitionists about Afro-Brazilian's role in the fight for ending slavery, which would relegate to the slave an essentially passive role, leaving to the (white) elites the responsibility for the Abolition. ${ }^{44}$ The emergence of an alleged habitus of inability or compliance is not, as already stated, an accurate reflection of the (in)action of slaves in the plane of reality, but a perception or a constituent element of the worldview from which the cartoonist is a representative and diffuser. This perception does not always appear explicitly in the Agostinian drawings, which depicts in some of them slave trails and rebellions ${ }^{45}$. It is possible to see a constant provocation, as if the representations of the trails were opposed to representations of inertia, just to remind us that the rebellion is an exception. In this sense, other drawings that show the slaves rebelling against the status quo stand as a chimera, a possibility that is always found in the future, as Image 7 shows.

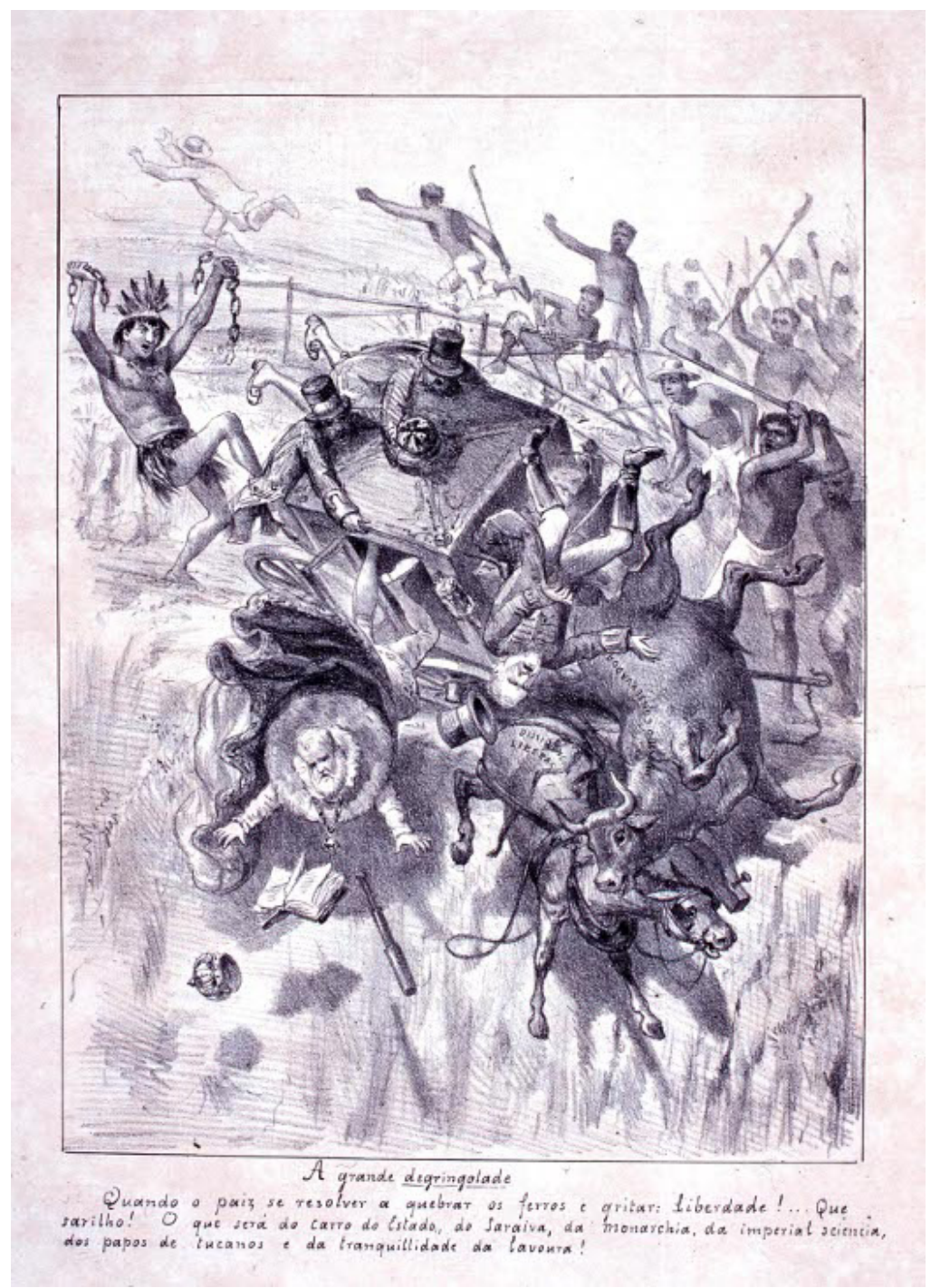

Image 7. AGOTINI, Ângelo. A Grande Degringolada. In: Revista Illustrada. № 415, Rio de Janeiro, jul. 1885. 
Quando o país se resolver a quebrar os ferros e gritar liberdade! Que sarilho!

47

"...the trace of the cartoons in the Monarchy has no autonomy of significance by itself, do not assume that it has his own speech, built by the lines that compose it. Thus, their role in the narrative structure of the cartoon is used to support text - long-winded, redundant, rebarbative - illustrating the story that it tells." (TEIXEIRA, Luíz Guilherme Sodré. O Traço como Texto - A História da Charge no Rio de Janeiro de 1860 a 1930. Rio de Janeiro: Edições Casa de Rui Barbosa, Coleção Papéis Avulsos n. 38. 2001. p. 13).
Despite the apparent rebellion in the picture, the caption shows that it is a fantasy of the cartoonist, a hope for a distant future. It reads: "When the country is resolved to break the irons and shout freedom! What a trouble!" 46 The emperor loses his crown and Africans and Natives push his car off the cliff. But this warrior and maverick spirit is saved for the future. For now, the slave keeps his habitus of inertia and conformism.

The pictorial discourse becomes the key to the scrutiny of immanent elements of the cartoon. Unlike stated by Teixeira ${ }^{47}$, the images have their own dynamic and hold the keys to their own understanding, or are even self-evident structures. Taking the images analyzed here, only Image 6 has a strong and direct connection to its caption, and even so it presents its own important pictorial elements that deserve to be analyzed in a self-referential manner, although the textual elements are always an important part of the analysis. The images become even more important when we think of their most banal feature - and at the same time most memorable. They give the reader a unique and closed composition, which is more easily remembered and thus have greater influence on the collective mentality.

It is through a qualitative analysis of elements like these (planimetric construction, scenic composition, character's performativity, the use of metaphors, etc.) that the mapping of structures of thought that permeated the production of Angelo Agostini is enabled, providing a privileged access to the mindset of the period and of the artist. The study of this structure is even more relevant when we consider the new reality of the Brazilian Empire, with its public opinion in formation, and the role played by Agostini. If he is frequently pointed as the main Brazilian cartoonist of the nineteenth century, his work is at the forefront of the production of world views in the period. His traces reveal, through laughter, mockery and criticism, a whole image of Brazil in the Empire's twilight.

\section{BIBLIOGRAPHY}

Primary Sources

AGOSTINI, Ângelo. De Volta do Paraguai. In: Revista Vida Fluminense. Rio de Janeiro, №. 12, jun. 1870.

. Preto e Amarello. In: Revista Illustrada. Rio de Janeiro, № 258, jul. 1881. . A Grande Degringolada. In: Revista Illustrada. № 415, Rio de Janeiro, jul. 1885.

PORTO ALEGRE, Manuel de Araújo. A Campainha e o Cujo. Litogravura. 1837. Fund. Biblioteca Nacional.

\section{Bibliography}

ACCARDO, Alain et.al. Journalistes au quotidien - Outils pour une socioanalyse des pratiques journalistes. Bordeaux: Le Mascaret, 1995. ARGAN, Giulio Carlo. Arte Moderna. São Paulo: Cia. das Letras, 1998.

AUGUSTO, José Carlos. Um Provinciano na Corte - As Aventuras de "Nhô-Quim" e a Sociedade do Rio de Janeiro nos anos 1860-1870. Dissertação (Mestrado em História Social), Universidade de São Paulo (USP), São Paulo, 2008.

AZEVEDO, Celia Maria Marinho de. Anti-racismo e seus Paradoxos. São Paulo: Annablume, 2004.

BALABAN, Marcelo. Poeta do Lápis: A Trajetória de Ângelo Agostini no Brasil Imperial - São Paulo e Rio de Janeiro - 1864-1888. Tese de Doutorado 
em História, Universidade Estadual de Campinas (Unicamp),

Campinas, 2005.

BERGSON, Henri. O Riso. São Paulo: Martins Fontes, 2001.

BOHNSACK, Ralf. Qualitative Bild- und Videointerpretation. Opladen:

Budrich, 2009.

. A Interpretação de Imagens e o Método Documentário. In:

Sociologias. Porto Alegre, n. 18, jun.dez 2007. p. 286-311.

BOURDIEU, Pierre. Le Sens pratique. Paris: Les Éditions de Minuit, 1980.

CAMPELLO, Silvio; CAVALCANTE, Sebastião. Ilustração e Artes Gráficas Periódicos da Biblioteca pública do Estado de Pernambuco. São Paulo: Blucher, 2014.

CHIAVENATTO, Júlio José Chiavenatto. O Negro no Brasil. São Paulo: Brasiliense, 1986.

DEZIM, Rogério. Matizes do Amarelo - elementos formadores do imaginário sobre o japonêns no Brasil. São Paulo : Arquivo Público do Estado de São Paulo. Disponível em : <http://www.usp.br/proin/download/ artigo/artigo_matizes_amarelo.pdf> [acessado em 10 abr. 2013].

DOMINGUES, Petrôneo. Uma História não contada: negro, racismo e branqueamento em São Paulo no pós-abolição. São Paulo: Senac, 2003.

DRESCHER, Seymour. Abolição - Uma História da Escravidão e do Escravismo. São Paulo: Unesp, 2011.

DUARTE, Paulo de Queiroz. Os Voluntários da Pátria na Guerra do Paraguai. Rio de Janeiro: Bibliex, 1981.

GAY, Peter. A Experiência Burguesa da Rainha Vitória a Freud - 0 Cultivo do Ódio. São Paulo: Cia. das Letras, 1995.

HOLLANDA, Sérgio Buarque de (org.). História Geral da Civilização Brasileira, t. II: 0 Brasil Monárquico, 5․ vol. Do Império à República. Rio de Janeiro, São Paulo: DIFEL, 1977.

IMDAHL, Max. Giotto Arenafresken: Ikonographie - Ikonologie - Ikonik. München: Fink, 1996.

JOBLING, Paul; CROWLEY, David. Graphic Design: Reproduction \& Representation since 1800. Manchester: Manchester University Press, 1996.

LIMA, Herman. História da Caricatura no Brasil. v. 01. Rio de Janeiro: José Olympio, 1963.

LIEBEL, Vinícius. Politische Karikaturen und die Grenzen des Humors und der Gewalt - eine dokumentarische Analyse der nationalsozialistischen Zeitung Der Stürmer. Opladen: Budrich Unipress, 2011.

. Entre Sentidos e Interpretações: apontamentos sobre a análise documentária de imagens. In: ETD - Educação Temática Digital. Campinas, v. 12, n. 2, 2011. p. 172-189.

MACHADO, Maria Helena Pereira Toledo. Crime e Escravidão - trabalho, luta e resistência nas lavouras paulistas 1830-1888. São Paulo: Brasiliense, 1987.

. From Slave Rebels to Strikebreakers: The Quilombo of Jabaquara and the Problem of Citizenship in Late-Nineteenth-Century Brazil. In: The Hispanic American Historical Review, Estados Unidos, v. 86, n. 2, 2006. p. 247-274.

MANNHEIM, Karl. Wissenssoziologie - Auswahl aus dem Werk. Berlin / Neuwied: Luchterhand, 1964.

MARINGONI, Gilberto. Ângelo Agostini ou impressões de uma viagem da Corte à Capital Federal ('864-1910). Tese (Doutorado em História Social), Universidade de São Paulo (USP), São Paulo, 2006. 
MATTOS, Hebe. Das Cores do Silêncio. Rio de Janeiro: Nova Fronteira, 1998. . 0 Herói Negro no ensino de História do Brasil: representações e usos das figuras de Zumbi e Henrique Dias nos compêndios didáticos brasileiros. In: ABREU, Martha et. al. (org.). Cultura Política e Leituras do Passado: historiografia e ensino de história. Rio de Janeiro:

Civilização Brasileira, 2007.

MELO, José Marques de. História Social da Imprensa. Porto Alegre: Edipucrs, 2003.

MELOT, Michel. Daumier, l'Art et la République. Paris: Les Belles Lettres, 2008. NERY, Laura. Sentidos do humor: Henrique Fleiüss e as possibilidades de uma sátira bem-comportada. In: KNAUSS, P., VELLOSO, M. P., OLIVEIRA, C., MALTA, M. (Org.). Revistas Ilustradas. Modos de ler e ver no Segundo Reinado. Rio de Janeiro: Mauad X/Faperj, 2011. p. 173-187.

MOREL, Marco. As Transformações dos Espaços Públicos - imprensa, atores políticos e sociabilidade na cidade imperial (1820-1840). São Paulo: Hucitec, 2005.

NABUCO, Joaquim. "O Mandato da Raça Negra." In: CARNEIRO, Edison (org.). Antologia do Negro Brasileiro. Rio de Janeiro: Agir, 2005.

PEREIRA, Washington Kuklinski. O Traço e a Pena - A Campanha Abolicionista de Ângelo Agostini na Revista Illustrada (1884-1888). Dissertação (Mestrado em História Social), Pontifícia Universidade Católica de São Paulo (PUC-SP), São Paulo, 2010.

SALGUEIRO, Heliana Angotti. A Comédia Urbana - de Daumier a Porto Alegre. São Paulo: Fund. Armando Álvares Penteado, 2003.

SALLES, Ricardo. Guerra do Paraguai - escravidão e cidadania na formação do exército. São Paulo: Paz e Terra, 1990.

SCHWARCZ, Lilia Moniz. Retrato em Branco e Negro - Jornais, Escravos e Cidadãos em São Paulo no final do século XIX. São Paulo: Círculo do Livro, 1989.

SILVA, Eduardo. As Camélias do Leblon. São Paulo: Cia das Letras, 2004.

SILVEIRA, Mauro César. A Batalha de Papel - a charge como arma na guerra do Paraguai. Florianópolis: Ed. UFSC, 2009.

SKIDMORE, Thomas. Preto no Branco: Raça e Nacionalidade no Pensamento Brasileiro. Rio de Janeiro: Paz e Terra, 1976.

SMITH, Woodruff D. The Ideological Origins of Nazi Imperialism. Oxford: Oxford University Press, 1989.

SODRÉ, Nelson Werneck. História da Imprensa no Brasil. Rio de Janeiro: Civilização Brasileira, 1966.

TEIXEIRA, Luíz Guilherme Sodré. O Traço como Texto - A História da Charge no Rio de Janeiro de 1860 a 1930. Rio de Janeiro: Edições Casa de Rui Barbosa, Coleção Papéis Avulsos n. 38, 2001.

TELLES, Angela Cunha da Motta. Desenhando a Nação: revistas ilustradas do Rio de Janeiro e de Buenos Aires nas décadas de 1860-1870. Brasília: Fund. Alexandre de Gusmão, 2010.

WELLER, W. A contribuição de Karl Mannheim para a pesquisa qualitativa: aspectos teóricos e metodológicos. In: Sociologias. N. 13. Porto Alegre. Jan-Jun. 2005.

. Minha Voz é tudo que eu tenho. Belo Horizonte: UFMG, 2011.

WELLER, Wivian; PFAFF, Nicole. Metodologias da Pesquisa Qualitativa em Educação. Petrópolis: Vozes, 2010. 